Vol. 13 (2004): 276-294.

\title{
Phosphorus status of diverse soils in Finland as influenced by long-term $P$ fertilisation 2. Changes of soil test values in relation to $P$ balance with references to incorporation depth of residual and freshly applied $P$
}

Into Saarela

MTT Agrifood Research Finland, Environmental Research, FI-31600 Jokioinen, Finland, e-mail: into.saarela@mtt.fi

Aulis Järvi

MTT Agrifood Research Finland, South Ostrobothnia Research Station, Alapääntie 104, FI-61400 Ylistaro, Finland

Heikki Hakkola

MTT Agrifood Research Finland, North Ostrobothnia Research Station, Tutkimusasemantie 15, FI-92400 Ruukki, Finland

Kalle Rinne

MTT Agrifood Research Finland, North Savo Research Station, Halolantie 31 A, FI-71750 Maaninka,

Finland

Fertilising with phosphorus $(\mathrm{P})$ ensures continuous supply of an essential growth factor as necessary for productive and sustainable agriculture. The amounts of $\mathrm{P}$ required to attain and maintain an adequate $\mathrm{P}$ status in the soil were investigated in field experiments at 22 sites in Finland on soils containing large amounts of residual fertiliser P. The effects of five rates $\left(0,15,30,45\right.$ and $\left.60 \mathrm{~kg} \mathrm{ha}^{-1}\right)$ of annual $\mathrm{P}$ application were measured in the soil by chemical methods after 9 to 15 experimental years, and the changes in soil test P values (STP) were compared with P balances. Stratification of P in ley soil by broadcast application of fertilisers was assessed at four sites. The mean changes of STP in the whole topsoil caused by $\mathrm{P}$ fertilisation expressed as per cent of the balance difference were 3.5\% $\left(0.0159 \mathrm{mg} \mathrm{dm}^{-3}\right) /\left(\mathrm{kg} \mathrm{ha}^{-1}\right)$ in the acid ammonium acetate test $\left(\mathrm{P}_{\mathrm{Ac}}\right), 4.7 \%\left(0.0214 \mathrm{mg} \mathrm{dm}^{-3}\right) /\left(\mathrm{kg} \mathrm{ha}^{-1}\right)$ in water extraction $\left(\mathrm{P}_{\mathrm{w}}\right)$ and $9.7 \%\left(0.058 \mathrm{mg} \mathrm{kg}^{-1}\right) /\left(\mathrm{kg} \mathrm{ha}^{-1}\right)$ in sodium bicarbonate extraction (modified Olsen $\mathrm{P}$ ). Initially high $\mathrm{P}_{\mathrm{Ac}}$ values tended to slowly decrease at zero $\mathrm{P}$ balance, while low values 
Vol. 13 (2004): 276-294.

did not change without some particular reason, such as soil acidification or mixing of the topsoil with some of the less fertile subsurface soil. A thin layer of the uppermost soil was quickly enriched by broadcast application of $\mathrm{P}$ fertiliser.

Key words: Acetate extractable P, Olsen P, sampling depth, total P, water extractable P

\section{Introduction}

The amounts and chemical fractions of phosphorus $(\mathrm{P})$ in Finnish soils were discussed in a recent review (Saarela 2002) and reported for 24 experimental sites (Saarela et al. 2003). Native $P$ reserves are fairly abundant in Finnish soils but occur mostly in stable inorganic and organic compounds which are poorly available to plants. The long-term balance surplus which markedly improved the P status in a major part of the cultivated soils in Finland has primarily increased the secondary inorganic fractions assumed to be bound to $\mathrm{Al}$ and $\mathrm{Fe}(\mathrm{Al}, \mathrm{Fe}-\mathrm{P})$. In some virgin mineral soils the mean size of this $\mathrm{P}$ pool was about $250 \mathrm{~kg} \mathrm{ha}^{-1}$, in cultivated minerals soils studied in the early $1960 \mathrm{~s}$ it was $550 \mathrm{~kg} \mathrm{ha}^{-1}$ and in the 18 mineral soils of this study sampled in 1977-1981 it was approximately $850 \mathrm{~kg} \mathrm{ha}^{-1}$. The relative changes in the inorganic $P$ fractions have been still larger in organic soils than in mineral soils. Repeated broadcast applications of fertilisers on untilled soil according to the common practice in ley enrich the surface efficiently with extractable and potentially transportable $P$ (Saarela 1992a), while mixing the rich topsoil with the poorer subsurface soil by deep tillage decreases the STP values (Saarela et al. 2000, Peltovuori 2002).

The STP values determined by the acid ammonium acetate method $\left(\mathrm{P}_{\mathrm{Ac}}\right)$, which is used in agricultural practice and mainly indicate the intensity factor of soil P status, have increased relatively about as sharply as the less soluble P reserves. The high rates of $\mathrm{P}$ fertilisation generally applied since the late 1940s have more than doubled the $\mathrm{P}_{\mathrm{Ac}}$ values in Finnish soils. The average application of fertiliser $\mathrm{P}$ to field crops was about $30 \mathrm{~kg} \mathrm{ha}^{-1}$ in the $1970 \mathrm{~s}$ and $1980 \mathrm{~s}$, but it dropped to $12 \mathrm{~kg} \mathrm{ha}^{-1}$ during the 1990s. During the last decades the input in manure has been almost $10 \mathrm{~kg} \mathrm{ha}^{-1}$ and the offtake in crops somewhat larger. The balance surplus is small but probably positive though all outputs including the reforestation of fertilised fields are taken into account (Saarela 2002). In spite of the improved supply of $\mathrm{P}$ from the soil, significant yield responses to $\mathrm{P}$ fertilisation were common in almost all field crops (Saarela et al. 1995). Nowadays almost $50 \%$ of the arable land of Finland is cropped with cereals, about $30 \%$ with intensive grass ley and 1.4 to $3 \%$ with rapeseed, sugar beet and potato.

For optimising long-term $\mathrm{P}$ fertilisation of crops grown on soils containing large amounts of accumulated $\mathrm{P}$, field experiments were established at 24 sites on diverse soils in Finland. A more detailed introduction to the research project together with physical and chemical characteristics and the initial P status of the experimental soils were presented earlier (Saarela et al. 2003). According to the $\mathrm{P}_{\mathrm{Ac}}$ values, the average initial $\mathrm{P}$ status of these soils was slightly better than that obtained in routine soil testing for the whole country at the same time. The mean initial $\mathrm{P}_{\mathrm{Ac}}$ value for the 24 soils was $13.1 \mathrm{mg} \mathrm{dm}^{-3}$, which is exactly the same as that obtained for 705 Finnish soils in a recent monitoring study (MäkeläKurtto and Sippola 2002). The amounts of P extracted with water $\left(\mathrm{P}_{\mathrm{w}}\right.$, v/v $1 / 60$, mean $11.5 \mathrm{mg}$ $\mathrm{dm}^{-3}$ ) were usually similar to $P_{\mathrm{Ac}}$, but in some acid sandy soils where the bioavailability of $\mathrm{P}$ was exceptionally poor (Saarela et al. 1995, Saarela 1998), $P_{w}$ was lower than $P_{A c}$. A modified Olsen procedure, which is a more quantitative $\mathrm{P}$ test in acid soils, produced about fourfold the other STP values (mean $\mathrm{P}_{\mathrm{Olm}} 61 \mathrm{mg} \mathrm{kg}^{-3}$ ).

The changes in soil $\mathrm{P}$ status caused by different rates of $\mathrm{P}$ fertilisation during the 9 to 15 
Saarela, I. et al. Phosphorus status of Finnish soils and long-term P fertilisation

Table 1. Topsoil characteristics of soil groups (Saarela et al. 2003).

\begin{tabular}{llcccc}
\hline Soil group & $\begin{array}{l}\text { Sites } \\
\text { number }\end{array}$ & $\begin{array}{c}\text { Organic } \\
\mathrm{C}, \%\end{array}$ & $\begin{array}{c}\text { Clay, } \% \\
(<2 \mu \mathrm{m})\end{array}$ & $\begin{array}{c}\text { Bulk density, } \\
\mathrm{kg} \mathrm{dm}^{-3}\end{array}$ & $\mathrm{pH}_{\mathrm{w}}$ \\
\hline Clay and loam soils with lower STP, CLP1 & $1,3,4$ & 3.6 & 53 & 0.92 & 6.0 \\
Clay and loam soils with higher STP, CLP2 & $5,6,8$ & 4.0 & 31 & 1.00 & 6.0 \\
Silt and sand soils with lower STP, SSP1 & $9-11,14$ & 3.4 & 12 & 1.02 & 5.6 \\
Silt and sand soils with higher STP, SSP2 & $15-18$ & 2.5 & 19 & 1.00 & 6.3 \\
Organic soils, low to medium STP, OSPM & $19-22,24$ & 22.3 & n.d. & 0.53 & 4.8 \\
All soils & & $8.3^{2)}$ & $27^{1)}$ & $0.87^{2)}$ & $5.7^{2)}$ \\
\hline
\end{tabular}

n.d. $=$ not determined

$\mathrm{STP}=$ soil test $\mathrm{P}$ value

1) mineral soils $(\mathrm{n}=14)$

2) all soils $(\mathrm{n}=19)$

year's experimental period at 22 of the 24 sites are reported in this paper. Several chemical soil testing methods were used in the 19 soils briefly characterised in Table 1 and the acetate test was employed in other three soils. Two experiments were excluded because of short experimental period (23) or incomplete plant P data (13). Stratification of surface-applied $\mathrm{P}$ was assessed with additional ley plots at four of the sites.

\section{Material and methods}

\section{Treatments and cropping}

Single and triple (1988-) superphosphate (8.7 or $20 \%$ P) were used as P fertilisers, and one of them was applied each year (except at site 18, Saarela et al. 2003) at rates $0,15,30,45$ and 60 $\mathrm{kg} \mathrm{P} \mathrm{ha}^{-1}$. Most experiments were cropped with spring cereals in every year or in an irregular rotation with a few rapeseeds and winter cereals. Grass ley was the main crop at one site (21) and included in the rotation at five sites $(4,8$, 14, 16 and 18). Potato was grown at one site (18). To cereals, rapeseeds and potato the $\mathrm{P}$ fertiliser was drilled before sowing to a depth of $8 \mathrm{~cm}$ with the row distances of 12.5 or $15 \mathrm{~cm}$, and to ley the $\mathrm{P}$ source was broadcast at the beginning of the growing season. From the thirteenth experimental year onward (Exp. 8 from the tenth, not in Exp. 4) the P rates 30 and $60 \mathrm{~kg} \mathrm{ha}^{-1}$ were withdrawn in order to investigate the residual effects of previously applied P. At site 18, 5/3-fold P rates $\left(0-100 \mathrm{~kg} \mathrm{ha}^{-1}\right)$ were applied 8 times to potato during the 12 year's period resulting in 10/9-fold mean annual rates. The tillage effect of fertiliser drilling was usually equalised by treating the $\mathrm{P} 0$ controls with the drill without any fertiliser distribution.

At two sites (8 and 22, Saarela et al. 2003) each $\mathrm{P}$ rate was studied without and with liming, which doubled the treatments to ten. All treatments were established with four replicates using a randomised block layout, modified to avoid extreme adjacent $P$ rates. Thus, each simple $\mathrm{P}$ fertilisation experiment comprised 20 plots and the experiments with liming 40 plots. The differences of the treatments (probability of $\mathrm{F}$ and Tukeys' honestly significant differences, HSD) were tested by the analysis of variance using individual experiments as replications. In the regression calculus including all sites the limed parts were treated as separate experiments $(\mathrm{n}=24)$. Three acid soils $(4,11,24)$ were limed over the whole studied area in the early or middle years of the experimental period. These treatments were consider as common soil fertility control operations and were not separated in calculating the results. 
Vol. 13 (2004): 276-294.

Sufficient rates of nitrogen $(\mathrm{N})$ and potassium (K) fertilisers were applied (Saarela et al. 1995). A Finnish ammonium nitrate fertiliser formulated with a mixture of ground dolomite, "Oulunsalpietari", was used as the N source. This compound was physiologically less acid than the common NPK fertilisers, which contain more $\mathrm{NH}_{4}-\mathrm{N}$ and no lime. The chemical form of nitrogen was a major reason for the maintenance of $\mathrm{pH}$ at the initial level in most of the soils (Saarela et al. 1995). The size of the plots differed slightly depending on the field machinery used. Total plot width was 4 to $5 \mathrm{~m}$ and length was 12 to $24 \mathrm{~m}$. A $1.5-2.5 \mathrm{~m}$ wide and 10-16 $\mathrm{m}$ long area in the centre of each plot was harvested and sampled for plant and soil analyses. Plant residues were chopped and ploughed under.

Vertical movement of surface-applied P in ley was studied with additional short-term experiments at four sites $(1,11,21$ and 22, Saarela et al. 2003) by determining the $P_{A c}$ values separately for several thin layers. Of the six treatments made in four replications (Saarela 1992a) two were used in this study: control and $50 \mathrm{~kg} \mathrm{P}$ in superphosphate broadcast annually at the beginning of the growing season for four years. The two annual harvests caused a total balance deficit of $49-77 \mathrm{~kg} \mathrm{ha}^{-1}$ in the control and a balance surplus of $98-131 \mathrm{~kg} \mathrm{ha}^{-1}$ in the fertilised treatment.

\section{Soil and plant analyses}

Soil samples were obtained from two layers of each plot before the first fertiliser application in the spring of the establishing year and subsequently the autumn of the experimental years 3 , $6,9,12,15$ and 18 , of which the year 9,12 or 15 was used as the final year. The two sampled layers represented the ploughed topsoil to a depth of 20 or $25 \mathrm{~cm}$ and the subsurface soil within the next $20 \mathrm{~cm}$. Each sample comprised about 0.51 soil, which was a composite of five or more subsamples obtained with an auger. The initial samples and final (or the next before them) samples of the $\mathrm{P}$ rates 0,15 and $45 \mathrm{~kg} \mathrm{~kg} \mathrm{ha}^{-1}$ were prepared and analysed for total $\mathrm{P}, \mathrm{P}_{\mathrm{Ac}}, \mathrm{P}_{\mathrm{w}}$ and
$\mathrm{P}_{\mathrm{Olm}}$ employing the methods described earlier (Saarela et al. 2003).

Most of the longest-run experiments $(1,4,5$, $8,9,10,15,18$ and 22, Saarela et al. 2003) were also sampled to 40 or $60 \mathrm{~cm}$ in 3 or 4 layers and analysed by the acetate method (Saarela et al. 1995). The effects of $P$ fertilisation on the $P$ status of the subsoil are not presented in details but discussed shortly with some other long-term experiments conducted in Histosols in Finland and published in Finnish. For illustrating the importance of soil types and intitial P status, the experiments were divided into five soil groups formed according to: organic carbon percentage, texture/region and initial STP value; clay and loam soils with lower and higher STP (CLP1 and CLP2, CLPM when combined), silt and sand soils similarly as SSP1, SSP2 and SSPM, and all organic soils, OSPM (Saarela et al. 2003). The STP values of the five groups (and of a sandy peat deviating from the other four Histosols) are presented in Table 2.

According to recalculation of the data published by Vuorinen and Mäkitie (1955), the $\mathrm{P}_{\mathrm{Ac}}$ values of mineral soils are closely correlated with the $\mathrm{P}$ values determined by the better-known Morgan's sodium acetate method from which the Finnish method was modified (Saarela 2002), $\left(\mathrm{P}_{\text {Morgan }}=0.694 * \mathrm{P}_{\mathrm{Ac}}-0.27, \mathrm{n}=40, \mathrm{w}=1.5-\right.$ $\left.12, \mathrm{R}^{2}=0.89\right)$. A very simple correction factor (0.7) can be used in comparing these methods in mineral soils. Bulk density of soil was obtained with ground dry soil samples and the true BD values in the field were approximated according to Erviö (1970). Final P values of the three treatments were adequate because the relationship of STP and P balance was practically linear in each individual experiment. The modification of the Olsen method (by Sillanpää 1982, accidentally in this study) means a prolonged sodium bicarbonate extraction, $60 \mathrm{~min}$ vs. the normal $30 \mathrm{~min}$, which was found to increase the $\mathrm{P}_{\mathrm{Ol}}$ values by about $20 \% . \mathrm{P}_{\mathrm{Ac}}$ values were determined in every soil sample and their changes were examined by regression equations.

Harvested crops were analysed for $\mathrm{P}$ and macrocations by dry combustion and colorime- 
Saarela, I. et al. Phosphorus status of Finnish soils and long-term P fertilisation

Table 2. Differences in $\mathrm{P}$ balance of soil groups between the $\mathrm{P}$ fertilisation rates 0 and $45 \mathrm{~kg} \mathrm{ha}^{-1}$ and corresponding differences in soil test $\mathrm{P}$ values (STP), in absolute differences (mean) and in per cent of the differences in $\mathrm{P}$ balance $(\overline{\mathrm{x}}=$ mean, $\mathrm{s}=$ standard deviation).

\begin{tabular}{|c|c|c|c|c|c|c|c|c|c|c|c|c|c|c|}
\hline \multirow{3}{*}{$\begin{array}{l}\text { Soil } \\
\text { group }\end{array}$} & \multirow{3}{*}{$\begin{array}{l}\text { Number } \\
\text { of soils }\end{array}$} & \multirow{3}{*}{$\begin{array}{c}\Delta \mathrm{P}_{\text {balance }} \\
\mathrm{kg} \mathrm{ha}{ }^{-1}\end{array}$} & \multicolumn{3}{|c|}{$\Delta \mathrm{P}_{\text {total }}$} & \multicolumn{3}{|c|}{$\Delta \mathrm{P}_{\mathrm{Olm}}$} & \multicolumn{3}{|c|}{$\Delta \mathrm{P}_{\mathrm{Ac}}$} & \multicolumn{3}{|c|}{$\Delta \mathrm{P}_{\mathrm{w}}$} \\
\hline & & & \multirow[t]{2}{*}{$\mathrm{kg} \mathrm{ha}^{-1}$} & \multicolumn{2}{|c|}{$\%$} & \multirow[t]{2}{*}{$\mathrm{mg} \mathrm{kg}^{-1}$} & \multicolumn{2}{|c|}{$\%$} & \multirow[t]{2}{*}{$\mathrm{mg} \mathrm{dm}^{-3}$} & \multicolumn{2}{|c|}{$\%$} & \multirow[t]{2}{*}{$\mathrm{mg} \mathrm{dm}^{-3}$} & \multicolumn{2}{|c|}{$\%$} \\
\hline & & & & $\overline{\mathrm{x}}$ & $\mathrm{S}$ & & $\overline{\mathrm{x}}$ & $\mathrm{s}$ & & $\overline{\mathrm{x}}$ & $\mathrm{S}$ & & $\overline{\mathrm{x}}$ & $\mathrm{s}$ \\
\hline CLP1 & 3 & 609 & 207 & 34 & 12 & 27 & 4.3 & 2.8 & 4.1 & 0.65 & 0.38 & 3.9 & 0.62 & 0.24 \\
\hline CLP2 & 3 & 560 & 240 & 43 & 31 & 28 & 4.9 & 0.4 & 14.6 & 2.64 & 2.44 & 12.5 & 2.21 & 1.49 \\
\hline SSP1 & 4 & 529 & 315 & 62 & 27 & 18 & 3.3 & 1.0 & 3.6 & 0.66 & 0.18 & 3.3 & 0.60 & 0.50 \\
\hline SSP2 & 4 & 570 & 248 & 43 & 15 & 26 & 4.6 & 1.1 & 14.9 & 2.59 & 0.59 & 17.2 & 2.99 & 0.65 \\
\hline OSPM & 4 & 552 & 273 & 50 & 29 & 39 & 6.8 & 3.0 & 7.0 & 1.23 & 0.39 & 12.1 & 2.11 & 1.09 \\
\hline Soil 21 & 1 & 333 & 120 & 36 & & 77 & 23.1 & & 8.3 & 2.49 & & 30.3 & 9.10 & \\
\hline All soils & 19 & 550 & 253 & 47 & 23 & 30 & 5.8 & 4.7 & 8.8 & 1.59 & 1.26 & 11.1 & 2.12 & 2.08 \\
\hline
\end{tabular}

CLP1 = Clay and loam soils with lower STP, CLP2 = Clay and loam soils with higher STP, SSP1 = Silt and sand soils with lower STP, SSP2 = Silt and sand soils with higher STP, OSPM = Organic soils, low to medium STP

try or AAS (Kähäri and Nissinen 1978) or by wet combustion and ICP-AES, and for $\mathrm{N}$ by Kjeldahl digestion or NIR. The P balance of each treatment was calculated as the difference of the amounts of $\mathrm{P}$ applied in fertilisers and removed in harvested crops and compared with the corresponding changes in soil test values during the experimental period. The relationships between the changes in $\mathrm{P}_{\mathrm{Ac}}$ and the $\mathrm{P}$ balances were studied by model calculations.

\section{Results and discussion}

The mean length of the 19 experiments presented in Figs 1-4 was 12.7 seasons and fairly similar for each soil group (Tables 2 and 3). The corresponding balance difference between 0 and $45 \mathrm{~kg} \mathrm{P} \mathrm{ha}^{-1}$ was $550 \mathrm{~kg} \mathrm{P} \mathrm{ha}{ }^{-1}$. The balances based on tens of plant analyses for each treatment and site can be considered highly accurate. The amounts of total $\mathrm{P}$ and the STP values summed in Table 2 and presented in Figs 1-4 which were obtained from smaller numbers of samples are less reliable. However, the trends for each soil group can be considered meaningful and the means for all soils fairly accurate. Because all samples were analysed at the same time, significant analytical errors between the different sampling times were practically impossible, at least in total $\mathrm{P}$ which is certainly stable in stored dry soil samples.

\section{Changes in total $P$ with applied $P$}

Although significant analytical errors were improbable, the observed concentration of total $\mathrm{P}$ in the final mineral soil samples (Fig. 1) was substantially lower than was estimated on the basis of the initial values and the balances. A probable explanation for the apparent error is the unplanned mixing of the less rich subsoil with the topsoil by ploughing, as seen in one rich soil (8) and what possibly occurred to a significant extent at most of the sites. The apparent increase in the concentration of total $\mathrm{P}$ in organic soils (OSMP in Fig. 1) may be explained by a gradual decomposition of organic matter and the consequent reduction in soil mass. The strong demand for $\mathrm{P}$ by plants growing on the less fertile control plots has increased the amounts of $P$ removed from the deeper soil layers. The deep exploitation of $\mathrm{P}$ and a corresponding decrease in the 
Vol. 13 (2004): 276-294.

uptake from the topsoil was presumably largest in organic soils, in which the soil test values varied little with depth (Saarela at al. 2003). The final STP values of the subsoil differed with the rate of $\mathrm{P}$ application much more in Histosols than in mineral soils (Saarela et al. 1995).

The boundaries of the plots of long-term experiments are diffusible even in the horisontal direction because of solute and soil movements. The exchange of topsoil between adjacent plots caused by annual tillage could have affected the spatial distribution of $\mathrm{P}$ in the soil markedly during the last experimental years (Jaakkola et al. 1997, Sibbesen et al. 2000). Recent soil tests for a clay soil in Mietoinen suggest that soil mixing may occur more rapidly than estimated previously. Theoretically, this error would be largest with the lowest and highest fertiliser rates, 0 and $60 \mathrm{~kg} \mathrm{P} \mathrm{ha}^{-1}$, because the intermediate treatments were balanced with the negative and positive errors at opposite edges of the plots.
Transfer of fertilised soil from adjacent plots to the controls obviously decreased the measured differences of the total $\mathrm{P}$ values between the control treatment and the smallest rate of fertiliser application, which were smaller than estimated in all but one soil group (Fig. 1). The total pool of soil $\mathrm{P}$ was also influenced by leaching and erosion. Its transfer outside the plots, up to two $\mathrm{kg} \mathrm{ha}^{-1} \mathrm{y}^{-1}$ (Turtola 1999), was too small to be detected in total $\mathrm{P}$ determinations, but larger amounts of soluble and solid $\mathrm{P}$ removed from the topsoil were perhaps retained by the subsoil. Because of the disappearance of the smallest rate of applied $\mathrm{P}$, the observed mean difference in the amount of total topsoil $\mathrm{P}$ between the rates 0 and $45 \mathrm{~kg} \mathrm{ha}^{-1}$ was as low as $47 \%$ (Table 2). The analytical recovery of applied $\mathrm{P}$ was higher between the medium rates of $\mathrm{P}, 15$ and $45 \mathrm{~kg} \mathrm{ha}^{-1}$, on average $65 \%$. This is comparable to other studies (Yli-Halla 1989, Jaakkola et al. 1997) and can be considered as a reasonably high recovery

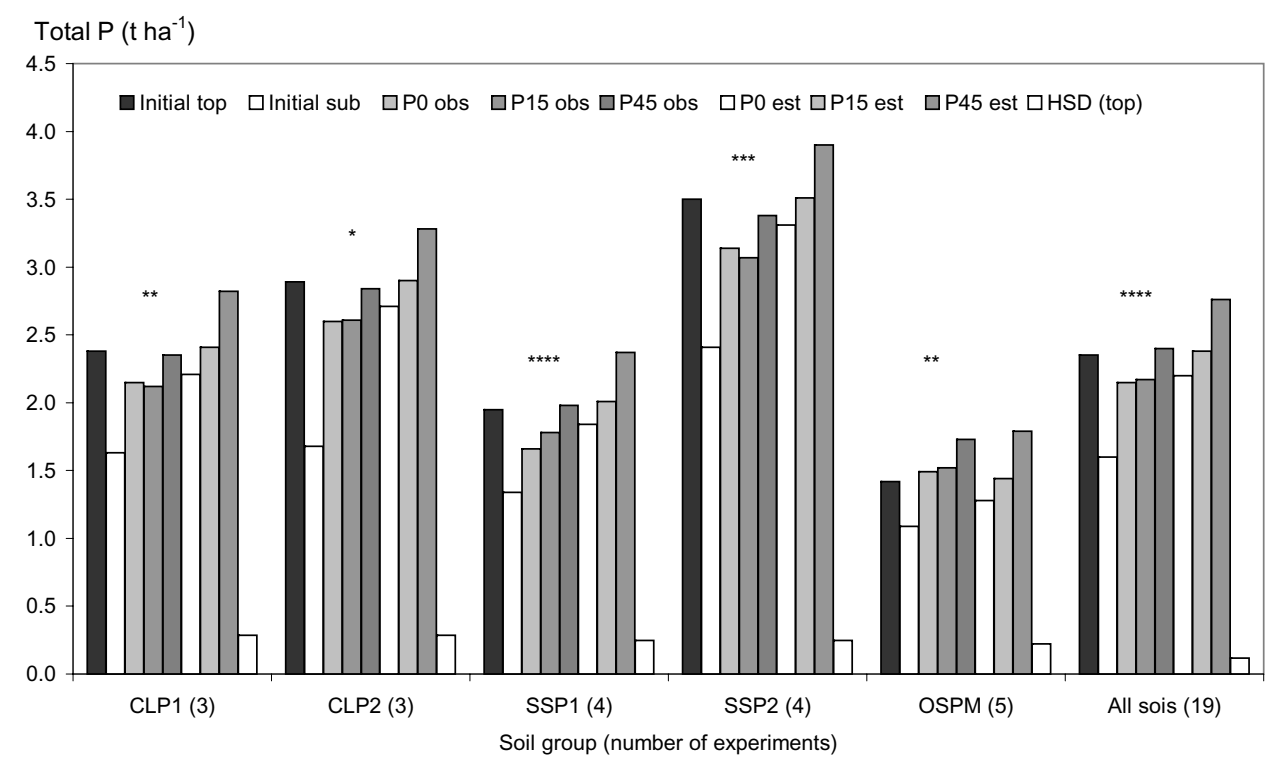

Fig. 1. Total amount of $P$ in the experimental soils by two layers at establishment (left) with observed (middle) and estimated (right) final values in the topsoil for three rates of annual P fertilisation. HSD = honestly significant difference for the four observed topsoil values at P 0.05 (based on the total error, $\mathrm{df}=$ 54). Asterisks indicate significant differences between the four observed topsoil values tested separately for each soil group at P $0.05(*), 0.01(* *), 0.001(* * *)$ and $0.0001(* * * *)$. Letters CL, SS, and OS by the soil groups denotes clay/loam soils, silty/sandy soils and organic soils, respectively. 
Saarela, I. et al. Phosphorus status of Finnish soils and long-term P fertilisation

under field conditions. The higher percentages of applied P previously recovered by Barkoff (1959) in the chemical fractionation of soil P may be explained at least in part by the infrequent tillage operations, as typical for the old ley-dominated crop rotation. The large pools of total $\mathrm{P}$ were clearly insensitive to moderate differences in $\mathrm{P}$ fertilisation.

\section{Changes in STP values with $P$ application}

The relative differences in the final STP values determined by the modified Olsen method $\left(\mathrm{P}_{\mathrm{Olm}}\right)$ presented in Table 2 and illustrated in Fig. 2 were much larger than those found in total P. Even the smallest application rate was distinguished from the control. The mean difference in $\mathrm{P}_{\mathrm{Olm}}$ between the rates 0 and $45 \mathrm{~kg} \mathrm{P} \mathrm{ha}^{-1}$ (47 and 77) was $30 \mathrm{mg} \mathrm{kg}^{-1}$, which according to the mean bulk density of $0.87 \mathrm{~kg} \mathrm{dm}^{-3}$ (Table 1) and the soil depth of $22 \mathrm{~cm}(1.91 \mathrm{Mg}$ soil ha-1) corresponds to $57.3 \mathrm{~kg} \mathrm{P} \mathrm{ha}^{-1}$. However, separate calculation of each soil gives of mean pool of 53.4 $\mathrm{kg} \mathrm{ha}^{-1}$, which is $9.7 \%$ of the corresponding difference in $\mathrm{P}$ balance, $550 \mathrm{~kg} \mathrm{ha}^{-1}$ (Table 2). Dividing the mean increase in $\mathrm{P}_{\mathrm{Olm}}$ by the corresponding difference in $\mathrm{P}$ balance (30/550) gives $0.054\left(\mathrm{mg} \mathrm{kg}^{-1}\right) /\left(\mathrm{kg} \mathrm{ha}^{-1}\right)$, but the mean of the ratios calculated separately for each soil (Table 2) is $0.058\left(\mathrm{mg} \mathrm{kg}^{-1}\right) /\left(\mathrm{kg} \mathrm{ha}^{-1}\right)$. The differences of the Olsen $\mathrm{P}$ values between the treatments (Fig. 2) were almost equal in all soil groups and varied little even within the groups, except for the weakly buffered sandy peat soil (21), which was included in the Histosol group in the Figs (1-4) but presented alone in the Tables (1-2).

The changes in $\mathrm{P}_{\mathrm{Olm}}$ are in agreement which previous results obtained for a fine-textured acid soil with short-term biological desorption studies by Yli-Halla et al. (2002). The final $\mathrm{P}_{\text {Olm }}$ values at $45 \mathrm{~kg} \mathrm{P} \mathrm{ha}^{-1}$ (Fig. 2) were relatively high

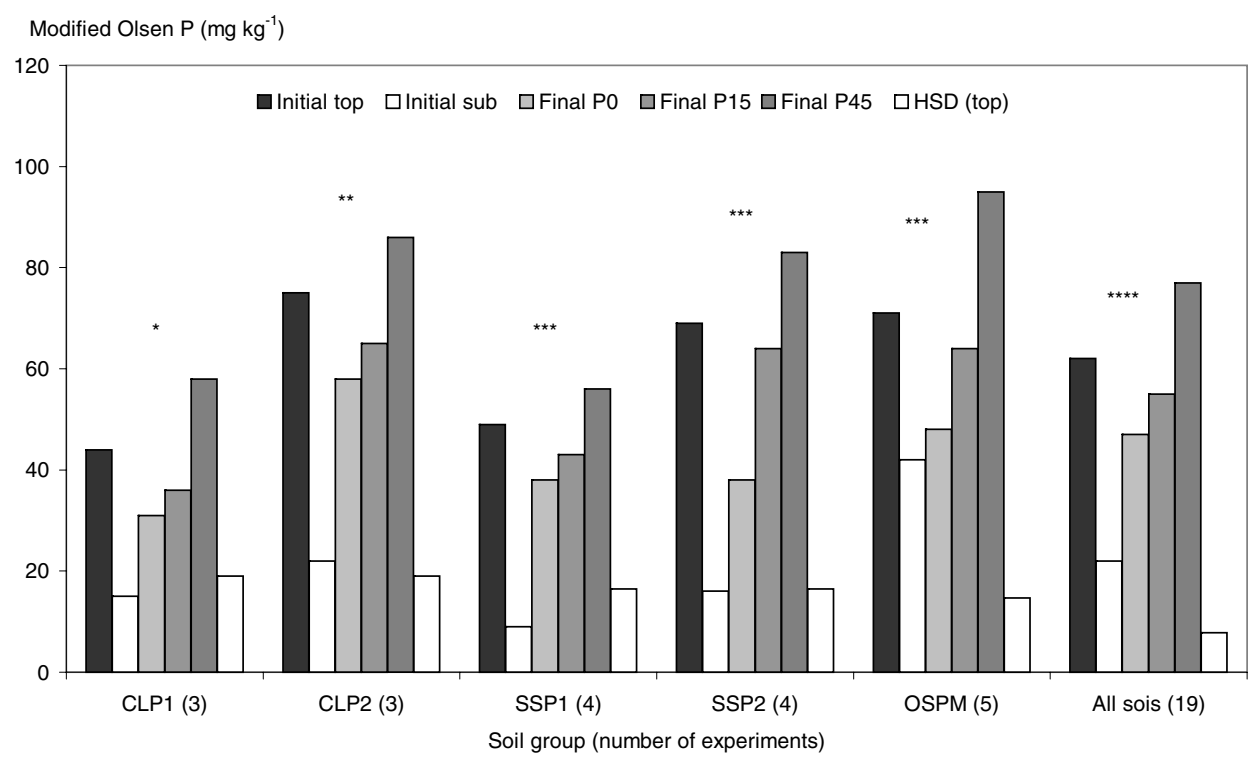

Fig. 2. Extractable $\mathrm{P}$ in the experimental soils as determined by the modified Olsen method for two layers at establishment and for three rates of annual P fertilisation after 9-15 experimental years in the topsoil. $\mathrm{HSD}=$ honestly significant difference for the four topsoil values at P 0.05 (based on the total error, $\mathrm{df}=54$ ). Asterisks indicate significant differences between the four topsoil values tested separately for each soil group at P $0.05(*), 0.01(* *), 0.001(* * *)$ and $0.0001(* * *)$. Letters CL, SS, and OS in the soil groups denotes clay/loam soils, silty/sandy soils and organic soils, respectively. 
Vol. 13 (2004): 276-294.

in all soil groups when compared with a global assessment (Sillanpää 1982). However, the bioavailability of P in Finnish soils is poorer (Sippola and Saarela 1986) and the leaching of soluble P to runoff water obviously slower (Turtola and Yli-Halla 1999) than this method indicates.

With the acetate and water extraction methods the recoveries of applied $\mathrm{P}$ were $3.5 \%$ for $\mathrm{P}_{\mathrm{Ac}}$ (or $\left.0.0159 \mathrm{mg} \mathrm{dm}^{-3}\right) /\left(\mathrm{kg} \mathrm{ha}^{-1}\right.$ in $\mathrm{P}$ balance $)$ and $4.7 \%$ for $\mathrm{P}_{\mathrm{w}}\left(0.0214 \mathrm{mg} \mathrm{dm}{ }^{-3}\right) /\left(\mathrm{kg} \mathrm{ha}^{-1}\right)$ in all soils, and with both methods, $3.6 \%(0.0163$ $\left.\mathrm{mg} \mathrm{dm}^{-3}\right) /\left(\mathrm{kg} \mathrm{ha}^{-1}\right)$ in mineral soils (Table 2 , recovery $=2.2 * \Delta \mathrm{STP}$ ). In the weakly buffered peat soil (21) the relative extraction efficiency was much higher in water extraction. P surpluses up to $500 \mathrm{~kg} \mathrm{ha}^{-1}$ during the experimental period (Table 3 ) were insufficient to raise the intensity factor of soil P status to a high level in the poorest soils, which efficiently fixed applied phosphate. For optimum yields, such problem soils require more applied $\mathrm{P}$ than is removed in the harvested crops (Saarela et al. 1995, Saarela 1998).

The critical STP value determined by the Morgan method in the soils of Vermont and New York of the United States, $4 \mathrm{mg} \mathrm{kg}^{-1}$, range 3-7 $\mathrm{mg} \mathrm{kg}^{-1}$ (Jokela et al. 1998) corresponds to 5.7 $\mathrm{mg} \mathrm{dm}{ }^{-3}$ (range $4.3-10 \mathrm{mg} \mathrm{dm}^{-3}$ ) $\mathrm{P}_{\mathrm{Ac}}$, and were

Table 3. Initial and final sampling years, $\mathrm{P}$ balance and soil $\mathrm{P}_{\mathrm{Ac}}$ without $\mathrm{P}$ fertilisation and the effect of annual application of $45 \mathrm{~kg} \mathrm{P} \mathrm{ha}^{-1}$ (difference between fertilised and control) with the ratio of the change in $\mathrm{P}_{\mathrm{Ac}}$ and $\mathrm{P}$ the balance. Letter $\mathrm{L}$ on experiment number means liming with $10 \mathrm{t} \mathrm{ha}^{-1}$ of ground limestone in 1980 . Soil characteristics presented earlier (Saarela et al. 2003).

\begin{tabular}{|c|c|c|c|c|c|c|}
\hline \multirow{2}{*}{$\begin{array}{l}\text { Experiment } \\
\text { number }\end{array}$} & \multirow{2}{*}{$\begin{array}{l}\text { Sampling year } \\
\text { Initial/final }\end{array}$} & \multicolumn{2}{|c|}{$\mathrm{P}$ balance, $\mathrm{kg} \mathrm{ha}^{-1}$} & \multicolumn{2}{|c|}{ Soil $\mathrm{P}_{\mathrm{Ac}}, \mathrm{mg} \mathrm{dm}^{-3}$} & \multirow{2}{*}{$\begin{array}{l}\Delta \mathrm{P}_{\mathrm{Ac}}, \% \text { of } \\
\Delta \text { balance }\end{array}$} \\
\hline & & Without P & $45 \mathrm{~kg} \mathrm{P} \mathrm{ha}^{-1}$ & Without P & $45 \mathrm{~kg} \mathrm{P} \mathrm{ha}^{-1}$ & \\
\hline 1 & $77 / 91$ & -160 & +651 & 2.4 & +4.4 & 0.68 \\
\hline 2 & $78 / 89$ & -132 & +528 & 2.4 & +6.7 & 1.27 \\
\hline 3 & $77 / 88$ & -121 & +532 & 6.1 & +1.4 & 0.26 \\
\hline 4 & $77 / 91$ & -234 & +645 & 3.9 & +6.6 & 1.92 \\
\hline 5 & $77 / 91$ & -179 & +659 & 6.8 & +12.3 & 1.87 \\
\hline 6 & $78 / 89$ & -122 & +498 & 7.1 & +3.4 & 0.68 \\
\hline 7 & $77 / 88$ & -114 & +529 & 9.9 & +3.8 & 0.72 \\
\hline 8 & $80 / 91$ & -217 & +524 & 31.5 & +28.2 & 5.38 \\
\hline $8 \mathrm{~L}$ & $80 / 91$ & -216 & +518 & 46.0 & +18.9 & 3.65 \\
\hline 9 & $79 / 93$ & -97 & +611 & 2.3 & +5.4 & 0.88 \\
\hline 10 & $77 / 88$ & -119 & +511 & 3.3 & +2.7 & 0.53 \\
\hline 11 & $77 / 91$ & -83 & +625 & 5.0 & +4.6 & 0.74 \\
\hline 12 & $77 / 88$ & -78 & +512 & 7.8 & +2.6 & 0.51 \\
\hline 14 & $78 / 86$ & -124 & +368 & 7.4 & +1.8 & 0.49 \\
\hline 15 & $77 / 91$ & -172 & +644 & 9.1 & +17.0 & 2.64 \\
\hline 16 & $78 / 89$ & -214 & +506 & 5.7 & +8.8 & 1.74 \\
\hline 17 & $77 / 88$ & -111 & +533 & 18.5 & +15.8 & 2.96 \\
\hline 18 & $81 / 92$ & -202 & +596 & 32.6 & +17.9 & 3.00 \\
\hline 19 & $77 / 88$ & -106 & +515 & 3.5 & +5.0 & 0.97 \\
\hline 20 & $78 / 89$ & -95 & +520 & 4.2 & +5.6 & 1.08 \\
\hline 21 & $78 / 87$ & -164 & +333 & 2.7 & +8.3 & 2.49 \\
\hline 22 & $80 / 91$ & -153 & +526 & 4.5 & +5.5 & 1.05 \\
\hline $22 \mathrm{~L}$ & $80 / 91$ & -159 & +526 & 4.2 & +6.1 & 1.16 \\
\hline 24 & $77 / 91$ & -168 & +647 & 11.3 & +11.7 & 1.81 \\
\hline Mean & & -148 & +544 & 9.9 & +8.5 & 1.57 \\
\hline
\end{tabular}


Saarela, I. et al. Phosphorus status of Finnish soils and long-term P fertilisation

reached at all sites with the highest $\mathrm{P}$ fertilisation rates. In Finland the American guidelines may be sufficient in the best clay and clay loam soils (Salonen and Tainio 1957, Jaakkola et al. 1977, Yli-Halla 1989, Saarela et al. 2000), but not in the biologically less fertile loam, silt loam and sandy soils (Sippola and Saarela 1986, Jaakkola et al. 1997).

The greater sensitivity of the water extraction and acetate tests than the modified Olsen method for the intensity factor of soil $\mathrm{P}$ status was apparent in the recovery of applied $\mathrm{P}$ in the mineral soils grouped by $\mathrm{P}_{\mathrm{Ac}}$ (Table 2, Figs. 3 and 4). The relative differences in the $\mathrm{P}_{\mathrm{Ac}}$ and $\mathrm{P}_{\mathrm{w}}$ values between the $\mathrm{P}$ fertilisation rates were similar in both poor and rich soils, but the absolute differences increased with the concentration of extractable P. These tests recovered only $1.3-$ $1.5 \%\left(0.0060-0.0066 \mathrm{mg} \mathrm{dm}^{-3}\right) /\left(\mathrm{kg} \mathrm{ha}^{-1}\right)$ of the calculated balance differences of $\mathrm{P}$ in poor min- eral soils $\left(5 \mathrm{mg} \mathrm{dm}^{-3}\right)$, but much more in rich soils. The relationships of the $\mathrm{P}_{\mathrm{Ac}}$ values and the balance of soil $\mathrm{P}$ were quantified by a regression equation based on 23 soils (Table 3, soil 21 excluded) and some values of the model are presented in Table 4. Although the correlation between the initial values and the changes was not particularly close $\left(\mathrm{R}^{2}=0.63\right)$, the small effects of application and removal of $\mathrm{P}$ on low $\mathrm{P}_{\mathrm{Ac}}$ values were demonstrated fairly convincingly.

The small changes in the concentration of extractable $\mathrm{P}$ in relation to the amount of applied $\mathrm{P}$ have been obtained earlier for several Finnish soils. In the long-term fertilisation experiments conducted by Salonen and Tainio (1957), applied $\mathrm{P}$ changed the typically low $\mathrm{P}_{\mathrm{Ac}}$ values of mineral soils by about $\left(0.01 \mathrm{mg} \mathrm{dm}^{-3}\right) /\left(\mathrm{kg} \mathrm{ha}^{-1}\right)$, and caused larger differences with originally higher values as well as in organic soils. In the sandy soil at site 10 of this study assessed by Luos-

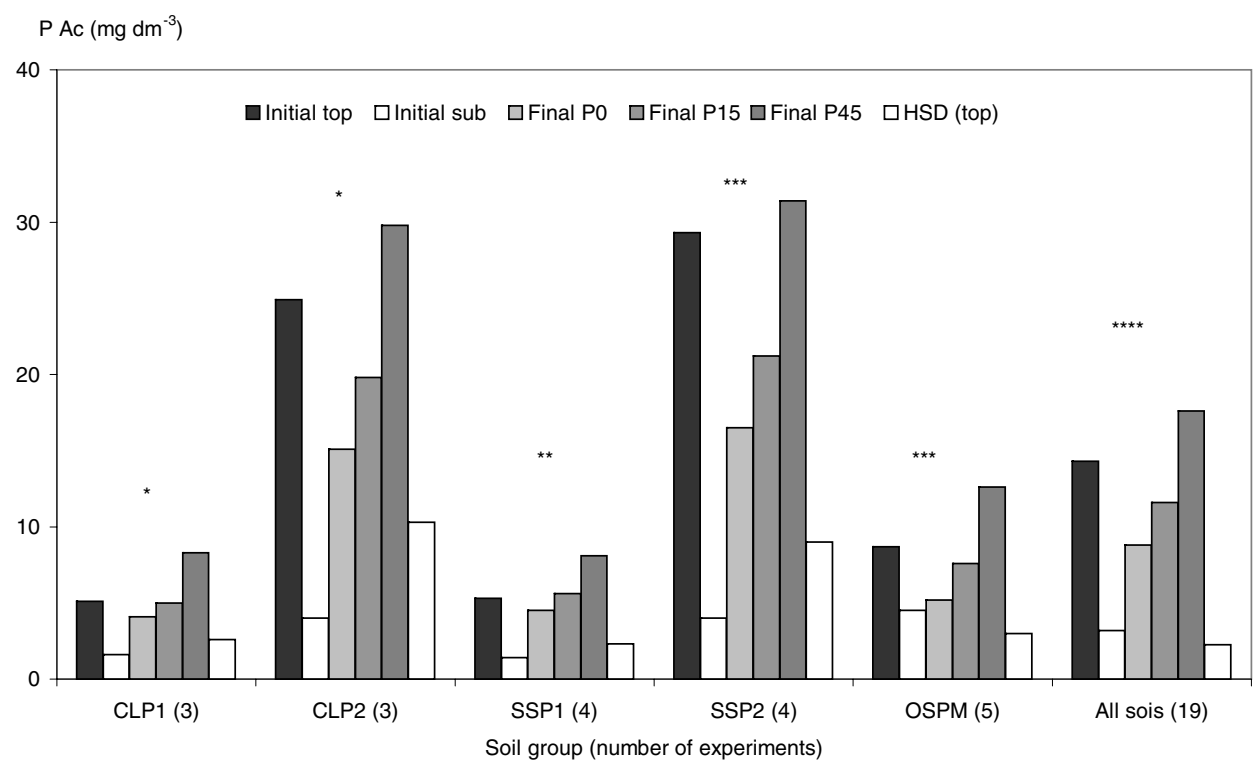

Fig. 3. Extractable $P$ in the experimental soils as determined by the acid ammonium acetate $\left(\mathrm{P}_{\mathrm{Ac}}\right)$ method for two layers at establishment with three rates of annual $\mathrm{P}$ fertilisation after 9-15 experimental years in the topsoil. HSD = honestly significant difference for the four topsoil values at P 0.05 (based on the total error, $\mathrm{df}=54)$. Asterisks indicate significant differences between the logarithms of the four topsoil values tested separately for each soil group at P $0.05(*), 0.01(* *), 0.001(* * *)$ and 0.0001 (****). Letters CL, SS, and OS in the soil groups denotes clay/loam soils, silty/sandy soils and organic soils, respectively. 
Vol. 13 (2004): 276-294.

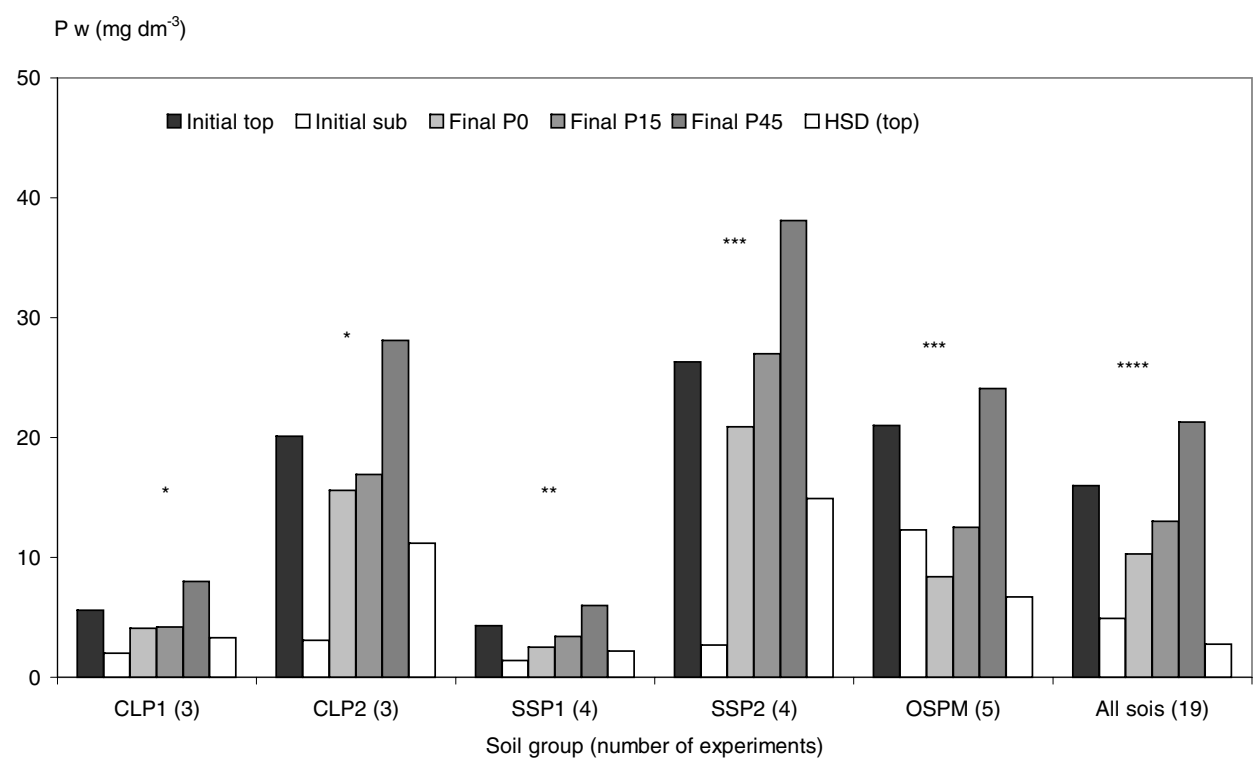

Fig. 4. Extractable $\mathrm{P}$ in the experimental soils as determined by the water $\left(\mathrm{P}_{\mathrm{w}}\right)$ extraction method for two layers at establishment and for three rates of annual $\mathrm{P}$ fertilisation after 9-15 experimental years in the topsoil. HSD = honestly significant difference for the four topsoil values at P 0.05 (based on the total error, $\mathrm{df}=54$ ). Asterisks indicate significant differences between the logarithms of the four topsoil values tested separately for each soil group at P 0.05 (*), 0.01 (**), 0.001 (***) and 0.0001 (****). Letters CL, SS, and OS in the soil groups denotes clay/loam soils, silty/sandy soils and organic soils, respectively.

tarinen (1967), $\mathrm{P}_{\mathrm{Ac}}$ values increased from 3.8 to $5.8 \mathrm{mg} \mathrm{dm}^{-3}$ with $440 \mathrm{~kg} \mathrm{P} \mathrm{ha}^{-1}$ applied in 20 years $\left(0.0045 \mathrm{mg} \mathrm{dm}^{-3}\right) /\left(\mathrm{kg} \mathrm{ha}^{-1}\right)$. Jaakkola et al. (1977 and unpublished data) measured $\mathrm{P}_{\mathrm{Ac}}$ values by which this ratio was about 0.0075 for 3 mineral soils and 0.015 for a peat soil. The changes in
$\mathrm{P}_{\mathrm{Ac}}$ appear to have been slightly larger in the oldest experiments, in which the incorporation depth of applied $\mathrm{P}$ was smaller than in later field studies.

The chemically dissimilar tests, $\mathrm{P}_{\mathrm{Ac}}$ and $\mathrm{P}_{\mathrm{w}}$, produced similar recovery percentages even for

Table 4. Final $\mathrm{P}_{\mathrm{Ac}}$ values at zero balance as function of the initial values and the $\mathrm{P}$ balance surplus required to maintain initial $\mathrm{P}_{\mathrm{Ac}}$ unchanged.

\begin{tabular}{|c|c|c|c|c|c|}
\hline $\begin{array}{l}\text { Initial } \mathrm{P}_{\mathrm{Ac}} \\
\mathrm{mg} \mathrm{dm}^{-3}\end{array}$ & $\begin{array}{l}\text { Final } \mathrm{P}_{\mathrm{Ac}} \\
\mathrm{mg} \mathrm{dm}^{-3}\end{array}$ & $\begin{array}{l}\text { Decrease } \\
\mathrm{mg} \mathrm{dm}^{-3}\end{array}$ & $\begin{array}{l}\left(\Delta \mathrm{P}_{\mathrm{Ac}} \mathrm{mg} \mathrm{dm}^{-3}\right) \text { per } \\
\left(\Delta \text { balance kg ha }^{-1}\right)^{1)}\end{array}$ & $\begin{array}{l}\text { Surplus for main } \\
\mathrm{kg} \mathrm{ha}^{-1}(12.5 \mathrm{y})^{-1}\end{array}$ & $\begin{array}{l}\text { al } P_{A c} \\
\mathrm{~kg} \mathrm{ha}^{-1} \mathrm{y}^{-1}\end{array}$ \\
\hline 2 & 1.88 & 0.12 & 0.0039 & 30 & 2 \\
\hline 5 & 4.48 & 0.52 & 0.0075 & 70 & 6 \\
\hline 12 & 10.32 & 1.68 & 0.0149 & 110 & 9 \\
\hline 25 & 20.36 & 4.64 & 0.0243 & 190 & 15 \\
\hline
\end{tabular}

1) $\left(\Delta \mathrm{P}_{\mathrm{Ac}}\right) /(\Delta$ balance $)=0.0013+0.001325 *$ initial $\mathrm{P}_{\mathrm{Ac}}-0.0000161 *$ (initial $\left.\mathrm{P}_{\mathrm{Ac}}\right)^{2}$. This empirical equation was calculated using the data presented in Table 3. The weakly buffered sandy peat of Experiment 21 was excluded $(\mathrm{n}=$ $\left.23, \mathrm{R}^{2}=0.63\right)$. 


\section{Saarela, I. et al. Phosphorus status of Finnish soils and long-term P fertilisation}

most of the individual mineral soils. Similar results were previously reported by Yli-Halla (1989) for two clay loam soils in Southern Finland, except for that the ratio $\mathrm{P}_{\mathrm{w}} / \mathrm{P}_{\mathrm{Ac}}$ was markedly higher in the less acid of the two soils $\left(\mathrm{pH}_{\mathrm{w}}\right.$ 6.0 vs. 5.4). In the short-term biological desorption study with rye grass performed with one of these soils (Yli-Halla et al. 2002) the changes in $\mathrm{P}_{\mathrm{w}}$ relative to the changes in inorganic $\mathrm{P}$ were much larger than in the long-term experiments $(1 /$ response index $=3.8-10 \%)$, but the decrease of the buffer power with increasing concentration of extractable $\mathrm{P}$ in the soil $\left(\mathrm{P}_{\mathrm{w}} 4.0-15.2 \mathrm{mg}\right.$ $\mathrm{dm}^{-3}$ ) was in agreement with the result of the present study.

Very close correlation between $\mathrm{P}_{\mathrm{w}}$ and diffusible P (Saarela 1992b) and other biological and chemical studies suggest that the water extraction method is an accurate indicator of the intensity factor of the P status of Finnish mineral soils. The low final $P_{w}$ values in spite of the large amounts of residual $\mathrm{P}$ in the soil (Fig. 4) are reliable indicators of a poor supply of $\mathrm{P}$ to plants as well as to the run-off water (Turtola 1999, Hooda et al. 2000). It means that P remains a growth limiting factor not only in agricultural soils but also in watercourses.

The five rates of $\mathrm{P}$ application were distinguishable as separate lines for $\mathrm{P}_{\mathrm{Ac}}$ at all sites (Saarela et al. 1995). Two examples are presented in Fig. 5. Freshly applied P was more efficient in raising the STP values than were older $P$ residues, particularly in the heavy clay soil. The regular lines for $\mathrm{P}_{\mathrm{Ac}}$ suggest that this soil test is an accurate indicator of the changes in the concentration of readily soluble $\mathrm{P}$ in soils, at least when the sampling and laboratory work is done as carefully as in research projects. The slow changes of the low and intermediate STP values at zero balance showed that soil $\mathrm{P}$ status is very stable if it is not influenced by some particular factor. On the other hand, changing the factors that control the balances between the different forms of soil $\mathrm{P}$ can affect the content of extractable $\mathrm{P}$ even without any net change in the total pool. Significant increases in STP can be expected after heavy liming (Lakanen and Vuo- rinen 1963, Jaakkola et al. 1977, Saarela and Sippola 1990, Saarela et al. 2000), and substantial decreases are probable after deep ploughing (Saarela et al. 2000, Peltovuori 2002).

Acid soils rich in active $\mathrm{Al}$ and $\mathrm{Fe}$ compounds resist effectively any changes of the concentration of $\mathrm{P}$ in soil solution and also the size of the most labile fractions measured by mild soil tests (Maguire et al. 2001), so these soils are strongly buffered for easily soluble phosphate. However, the efficient capacity to sorb applied P do not seem to affect the $\mathrm{P}$ status of soils improved with long-term application of $\mathrm{P}$ in amounts exceeding the offtake. Large amounts of recently applied $\mathrm{P}$ being not equilibrated as completely as older additions are slowly converted into less labile forms, as happened in the heavy clay with the discontinued $\mathrm{P}$ applications (Fig. 5).

\section{Effect of long-term $P$ fertilisation on Histosol profiles}

One of the six Histosols, a sandy Carex peat (21), exerted a weak capacity to sorb $\mathrm{P}$, and the differences in $\mathrm{P}_{\mathrm{Ac}}$ between the treatments increased rather sharply even in the subsurface soil, ranging from 1.6 to $4.7 \mathrm{mg} \mathrm{dm}^{-3}$ in the final samples (Saarela et al. 1995). This is a strong effect in relation to the 10 year's duration of the experiment and to the corresponding values in the topsoil, initial $8.0 \mathrm{mg} \mathrm{dm}^{-3}$ and final from 2.6 to $14.4 \mathrm{mg} \mathrm{dm}^{-3}$ with 0 and $60 \mathrm{~kg} \mathrm{P} \mathrm{ha}^{-1}$. Even more rapid effects of $\mathrm{P}$ fertilisation on the concentration of extractable $\mathrm{P}$ in the subsurface layer were measured in a cut-away peatland at Valkeasuo, Tohmajärvi (Virkajärvi and Huhta 1993), where $\mathrm{P}_{\mathrm{Ac}}$ varied from 0.3 to 4.7 or $9.5 \mathrm{mg} \mathrm{dm}^{-3}$, depending on fertilisation, in the sandy subsurface soil, and from 0.7 to 19.4 or $27.6 \mathrm{mg} \mathrm{dm}^{-3}$ in the topsoil.

The plough layer of the other five Histosols of this study exerted a moderate or fairly strong (22) capacity to retain $P$, but especially in the soil 22 amended with heavy clay, the mobility of $\mathrm{P}$ was much greater in the subsoil, and a significant effect of $\mathrm{P}$ fertilisation was measured 
Vol. 13 (2004): 276-294.
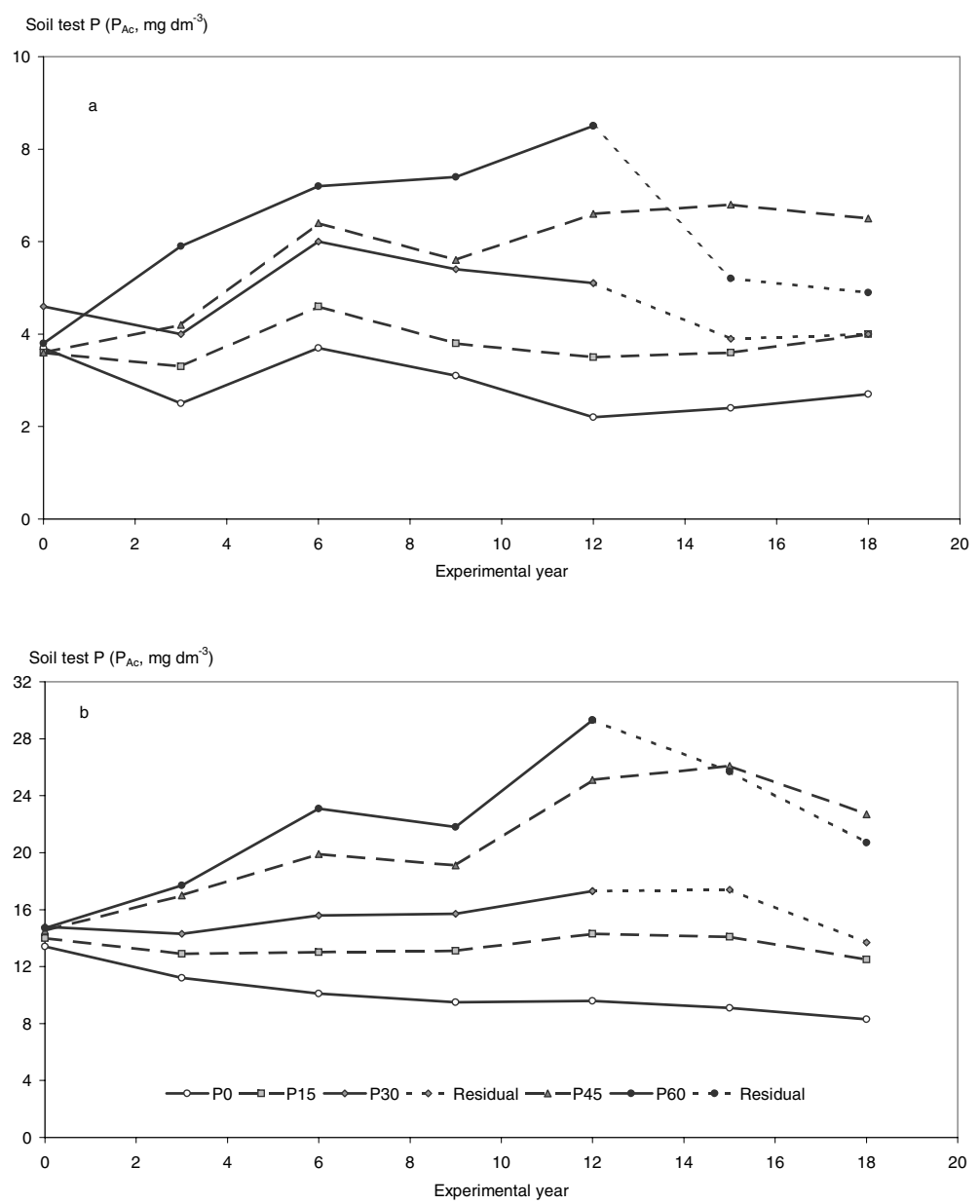

Fig. 5. Soil test $\mathrm{P}$ values determined by the acid ammonium acetate method with five rates of annual $\mathrm{P}$ fertilisation in clay soil at Mietoinen (Exp. 1, a) and in sandy loam soil at Maaninka (Exp. 15, b). down to the depth of 40-60 cm, where $\mathrm{P}_{\mathrm{Ac}}$ values were 2.0 and $3.4 \mathrm{mg} \mathrm{dm}^{-3}$ for the $\mathrm{P}$ fertilisation rates 0 and $45 \mathrm{~kg} \mathrm{ha}^{-1}$ (Saarela et al. 1995). The sharp increase in STP as response to P application has been found in several Histosols in Finland (Salonen and Tainio 1957, Saarela and Sippola 1990, Puustinen et al. 1994).

Even if the subsoil studies may have been affected by mixing of the subsoil samples with some of the topsoil, the differences between deep peat soils and mineral soils were large and reliably established. The rapid and deep effect of $\mathrm{P}$ fertilisation in peat soils agreed with the generally poor availability of $\mathrm{P}$ in newly cleared peat soil (Salonen and Tainio 1957), which means that a major part of the soluble $\mathrm{P}$ in the subsoil must originate from applied fertilisers.

Leaching studies were performed on Carex peat soil at the same site as the experiment 19 of this study (Huhta and Jaakkola 1993). Although the $\mathrm{P}_{\mathrm{Ac}}$ values at the depth of $0.2-0.7 \mathrm{~m}$ were as low as $2-3 \mathrm{mg} \mathrm{dm}^{-3}$, the leaching of soluble $\mathrm{P}$ in the drainage water was considerable, almost one $\mathrm{kg} \mathrm{ha}^{-1} \mathrm{y}^{-1}$. The risk of leaching of $\mathrm{P}$ through the soil to the drainage pipes because of a high degree of $\mathrm{P}$ saturation in the bulk soil is greatest in the weakly humified Histosols which contain little inorganic compounds capable to sorb P (Kai- 
Saarela, I. et al. Phosphorus status of Finnish soils and long-term P fertilisation

la 1959). In raised bogs the amounts of $P$ leached may be even hundred times larger than in mineral soils, as stated by Finck (1992) and measured in drainage water by Kuntze and Scheffer (1979).

\section{Final vs. initial $P_{A c}$ values at zero $P$ balance}

The $\mathrm{P}_{\mathrm{Ac}}$ values for the zero balance, at which the applied $P$ fertiliser exactly replaced the P offtake in harvested crops, were interpolated from the values of $\mathrm{P}_{\mathrm{Ac}}$ measured from the final soil samples. These final $\mathrm{P}_{\mathrm{Ac}}$ values at zero $\mathrm{P}$ balance were plotted with the initial values of the same test (Fig. 6). The amounts of $\mathrm{P}$ applied in seeds, up to one $\mathrm{kg} \mathrm{ha}^{-1} \mathrm{y}^{-1}$, which were probably not much larger than the leaching and erosion losses, were not included in the balance calculations. The correlation between the final and initial values was equally good with the linear equation $y$ $=0.694 x+1.4, \mathrm{R}^{2}=0.963$ as with the polynomial curve shown in the figure, but the polynomial curve is probably more accurate with very low STP values because of its smaller intercept.

The final value obtained from the polynomial function at the initial mean, $13.1 \mathrm{mg} \mathrm{dm}^{-3}$, was $11.3 \mathrm{mg} \mathrm{dm}^{-3}$, which represents a decrease of
$14 \%$ in 12 years. The decrease was about $10 \%$ at the mean $\mathrm{P}_{\mathrm{Ac}}$ of the poorer soil groups, $5 \mathrm{mg} \mathrm{P}$ $\mathrm{dm}^{-3}$, and $19 \%$ at the mean of the richer soils, 25 $\mathrm{mg} \mathrm{P} \mathrm{dm}^{-3}$ (Table 4). Model calculations indicate that the balance surplus required to prevent the slow decline in $\mathrm{P}_{\mathrm{Ac}}$ increases with the initial value. The amount of applied $P$ required to change the $\mathrm{P}_{\mathrm{Ac}}$ value by one unit decreased with $\mathrm{P}_{\mathrm{Ac}}$, but the relative change was larger in the decline of extractable $\mathrm{P}$ with time. The annual surplus in the $\mathrm{P}$ balance should have been $6 \mathrm{~kg} \mathrm{ha}^{-1}$ in the poorer soil groups and $15 \mathrm{~kg} \mathrm{ha}^{-1}$ in the richer groups, on average $10 \mathrm{~kg} \mathrm{ha}^{-1}$, to prevent the slow decreases of the concentration of soil P extracted with acid ammonium acetate (Table 4). In the twelve weakly acid to neutral Swedish soils investigated by Carlgren and Mattsson (2001) the requirement of surplus $\mathrm{P}$ for preventing any decrease in ammonium lactate extractable $\mathrm{P}\left(\mathrm{P}_{\mathrm{Al}}\right)$ was roughly similar than required in this study for maintaining $\mathrm{P}_{\mathrm{Ac}}$. However, the loss of $\mathrm{P}_{\mathrm{Al}}$ appeared to have decreased with time and even ceased during the later part of the experimental period of almost 30 years.

Little change in $\mathrm{P}_{\mathrm{Ac}}$ was recorded for 16 of the 24 soils if $\mathrm{P}$ offtake was compensated with fertiliser application (Fig. 6). Similar results were previously obtained by Jaakkola et al. (1977 and unbublished soil test data). Liming with 10

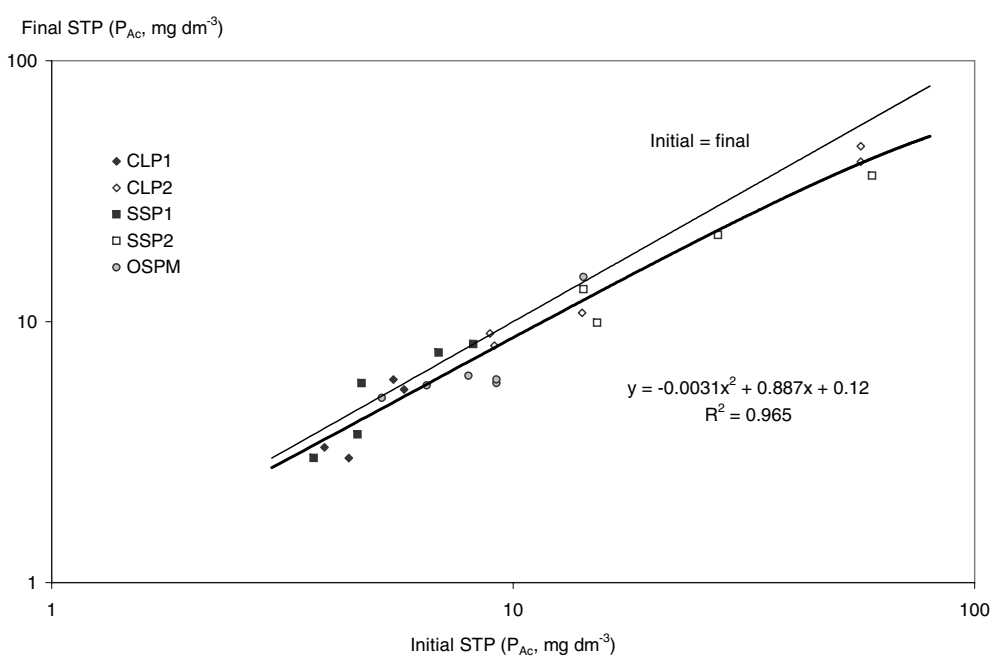

Fig. 6. Final and initial soil test $\mathrm{P}$ (STP) values for the experimental soils (22 sites, of which two with and without liming). The final values were determined after 9-15 experimental years and extrapolated for the $\mathrm{P}$ fertilisation rate of each soil at which the $\mathrm{P}$ balance is zero. Letters CL, SS, and OS in the soil groups denotes clay/loam soils, silty/sandy soils and organic soils, respectively. 
Vol. 13 (2004): 276-294.

t ha $\mathrm{a}^{-1}$ of ground limestone from $\mathrm{pH}_{\mathrm{w}} 5.3$ to 5.5 had little effect on the extractability of $\mathrm{P}$ in the clayey Carex peat at site 22. In the P-rich and almost neutral clay soil (8) heavy liming, from $\mathrm{pH}_{\mathrm{w}} 6.6$ to 7.0 , on the contrary, enhanced fairly efficiently the extraction of $\mathrm{P}$ by acid acetate, as usual in Finnish clay soils (Jaakkola et al. 1977, Saarela and Sippola 1990, Saarela et al. 2000). Weak or even negative effects of liming on the extractability of $\mathrm{P}$ are typical for Finnish organic soils, while particularly the $\mathrm{P}_{\mathrm{Ac}}$ values increase sharply in mineral soils when the $\mathrm{pH}_{\mathrm{w}}$ values raise over 6.5 (Lakanen and Vuorinen 1963, Jaakkola et al. 1977). The smaller changes in $P_{w}$ than in $\mathrm{P}_{\mathrm{Ac}}$ resulting from heavy liming (Saarela and Sippola 1990) show that the danger of P leaching is not increased with $\mathrm{pH}$ as sharply as the increase in the $\mathrm{P}_{\mathrm{Ac}}$ values suggest.

\section{Fixation of extractable $P$ in acidic and initially rich soils}

At the lower medium level of extractable P, the largest reduction of extractable $\mathrm{P}$ was recorded for the clayey Carex peat at site 22, which was highly infertile in 1949 (Saarela et al. 2003). In addition to the better-known chemical fixation, the accumulation of organic $\mathrm{P}$ as a result of biological fixation of soluble phosphate occurring in certain organic soils (Kaila and Missilä 1956, Kaila 1961), is a further possible explanation for the loss of acetate extractable $\mathrm{P}$ in this particular field. The large amounts of $\mathrm{Fe}$ and $\mathrm{Al}$ in the heavy clay ( $350 \mathrm{~g}$ clay $\mathrm{dm}^{-3}$ soil) previously applied to this soil (Saarela et al. 2003) perhaps weathered quickly in the new acidic and humic medium and phosphate was fixed unusually efficiently even chemically.

The decrease of $\mathrm{P}_{\mathrm{Ac}}$ was substantial in an acid clay loam (7) and a silty clay loam (16), which had a somewhat better than average initial P status. In addition to replacement of the offtake of $18.8 \mathrm{~kg} \mathrm{P} \mathrm{ha}^{-1}$, an annual balance surplus as high as $30 \mathrm{~kg} \mathrm{P} \mathrm{ha-1}$ was required in soil 16 to maintain its initial STP value unchanged. This field was cropped for seven years with ley grasses using heavy nitrogen dressings (Saarela et al. 1995), which were the most probable reason for the exceptional acidification of this soil from $\mathrm{pH}_{\mathrm{w}}$ 6.5 to 6.1 (Sillanpää and Rinne 1975). According to a long-term incubation experiment carried out by Lakanen and Vuorinen (1963), this increase in acidity is sufficient to explain most of the observed drop in $\mathrm{P}_{\mathrm{Ac}}$.

In conflict with most of the soils of this study but in a reasonable agreement with several equally acid fine to medium-textured soils, the fixation of extractable $\mathrm{P}$ appeared to be rather strong in two clay loam soils (31-37\% clay) in Southern Finland $(60.20 \mathrm{~N})$ studied by Yli-Halla (1989). At zero $\mathrm{P}$ balance, initial $\mathrm{P}_{\mathrm{Ac}}$ values of $5.4-6.0 \mathrm{mg} \mathrm{dm}^{-3}$ decreased to $3.2-3.8 \mathrm{mg} \mathrm{dm}^{-3}$, or by $40 \%$, in 11-12 years. In addition to the rather strong initial acidity $\left(\mathrm{pH}_{\mathrm{w}}\right.$ 5.4-6.0) and its gradual increase with applied ammonium compounds (Yli-Halla 1989), other reasons for the unusual sharp drop in extractable $\mathrm{P}$ in these soils seem to have been the low $\mathrm{P}$ saturation indices (4.4-5.2\%) in relation to the initial $\mathrm{P}_{\mathrm{Ac}}$ values and a substantial mixing of the unanalysed but usually poorer subsurface soil with the topsoil, which had been probable as a result of the deeper than average ploughing practised at the experimental farm. According to recent investigations by Peltovuori (2002), the $\mathrm{P}_{\mathrm{Ac}}$ values of mixtures were accurately predicted by the massweighted average values of their components, while the $P_{w}$ values were lower because of the efficient sorptive material in the subsurface soil.

A general decrease of very high STP values can be postulated from the final values of the richest soils of this study, in agreement with the values for another rich soil (Jaakkola et al. 1997). Mixing of the topsoil with some of the less fertile subsurface soil, as implied by the changes in total P, probably had a substantial influence even on the trend of final $P_{A c}$ as a function of the initial values (Fig. 6). This kind of mixing was observed to a significant extent in one of the two very rich fields (8). The effects of the mixing may increase with initial STP because of the parallel increase in the gradient in total P (Fig. 1); 


\section{Saarela, I. et al. Phosphorus status of Finnish soils and long-term P fertilisation}

the group SSP2 is untypical because of the naturally rich soil 15 (Saarela et al. 2003). Leaching of soluble $\mathrm{P}$ was probably a minor reducer of extractable $\mathrm{P}$ pools even in this kind of soils as indicated by the sharp decreases in the $\mathrm{P}_{\mathrm{Ac}}$ values with depth (Saarela et al. 1995, 2003). Enormous amounts of secondary inorganic $\mathrm{P}$ as determined in the profiles of some soils (Peltovuori et al. 2002) also support the possibility that the main cause of the losses of soluble $\mathrm{P}$ is its fixation and not leaching.

\section{Stratification of broadcast $P$ in ley}

As stated above, an increase of the depth of the fertile soil by mixing with subsoil was an obvious reason for the lower than estimated final concentration of total P and the STP values for the topsoils. Deep ploughing to the dept of 30$35 \mathrm{~cm}$ increases the yields markedly in coarse sandy soils and somewhat also in clay and clay loam soils, but would decrease the yields in unstable silty soils (Håkansson et al. 1998, Saarela et al. 2000). Deep ploughing or other deep incorporation techniques, which would improve the supply of $\mathrm{P}$ to plants during the dry periods in early summer typical in Finland (Saarela et al. 2000) and reduce the concentration of soluble $\mathrm{P}$ in the surface exposed to leaching (Peltovuori 2002), should be considered as a multipurpose technique in the agro-environmental management of $\mathrm{P}$ in cultivated soils.

The apparent balance within the total soil volume certainly includes spatial variation caused by localised entry and removal of phosphate. Fertiliser $\mathrm{P}$ when drilled to the soil have been found to be enriched only within a limited height and width (Aura 1967). Normal rates of placed $\mathrm{P}$ are fixed within $10-15 \mathrm{~mm}$ distance from the fertiliser bands and occupy less than $1 \%$ of the topsoil in very high concentrations (Saarela and Saarela 2000). When P fertiliser is broadcast on mineral soil and left on the surface, as is usually done in leys, applied P is retained by a thin layer of the uppermost soil and reaches readily very high concentrations within the limited soil volume (Hänninen and Kaila 1960, Haygarth et al. 1998). After a few years of annual dressings, which supplied a total of $50-78 \mathrm{~kg} \mathrm{P}$ ha $^{-1}$ on two silt loam soils, Hänninen and Kaila (1960) measured two to four times higher concentrations of "P in soil solution" for the uppermost $25 \mathrm{~mm}$ thick layer than for the next $50 \mathrm{~mm}$.

The assessment of the stratification of extractable P in ley at the four sites (Table 5) indicated that $200 \mathrm{~kg} \mathrm{P} \mathrm{ha}^{-1}$ broadcast on clay soil (close to site 1 of this study) was retained by the uppermost $25 \mathrm{~mm}$ thick layer for four seasons; in silt loam (11) and clayey peat (22) some of the applied $\mathrm{P}$ was leached to the next layer (25$50 \mathrm{~mm}$ ); in a sandy peat soil (21) which sorbed phosphate anions exceptionally weakly, the enrichment extended to the depth of 50-100 mm. In agreement with the studies by Hänninen and Kaila (1960), the results prove that normal rates of surface-applied $\mathrm{P}$ are retained by a thin, about $15-25 \mathrm{~mm}$ thick layer of the typical mineral soil of Finland which sorbs phosphate anions effectively. The concentration of extractable $\mathrm{P}$ in this

Table 5. Concentration of soil $\mathrm{P}$ extractable in acid ammonium acetate $\left(\mathrm{P}_{\mathrm{Ac}}, \mathrm{mg} \mathrm{dm}^{-3}\right)$ at various depths and the calculated mean for the whole plough layer $(0-20 \mathrm{~cm})$ in the control soils and in the soils topdressed annually with $50 \mathrm{~kg} \mathrm{P} \mathrm{ha}^{-1}$ for four years (Saarela 1992b). These experiments were conducted at the same sites as four of the 24 longterm experiments (Saarela et al. 2003)

\begin{tabular}{lcccccrr}
\hline Soil type & Site & \multicolumn{2}{c}{ Control fertilisation (no P) } & \multicolumn{3}{c}{ P application $4 * 50 \mathrm{~kg} \mathrm{ha}^{-1}$} \\
& & $0-2.5 \mathrm{~cm}$ & $10-20 \mathrm{~cm}$ & $0-20 \mathrm{~cm}$ & $0-2.5 \mathrm{~cm}$ & $10-20 \mathrm{~cm}$ & $0-20 \mathrm{~cm}$ \\
\hline Clay & 1 & 3.8 & 3.2 & 3.3 & 22.6 & 4.0 & 6.3 \\
Silt loam & 11 & 7.2 & 8.1 & 7.8 & 24.4 & 8.3 & 10.6 \\
Sandy peat & 21 & 3.0 & 4.0 & 3.5 & 24.5 & 4.1 & 7.5 \\
Clayey mull & 22 & 4.9 & 5.3 & 4.9 & 14.0 & 5.5 & 6.8 \\
\hline
\end{tabular}


Vol. 13 (2004): 276-294.

layer raises to a level several times higher than the mean for the whole plough layer measured by normal sampling. The effect of $\mathrm{P}$ fertilisation was three to five times greater in the $2.5 \mathrm{~cm}$ thick surface layer than in the $20 \mathrm{~cm}$ deep topsoil, which means that three ley years correspond to more than then years of the conventional cultivation including annual ploughing. Although the conventional sampling prevented any analytical proof, the status was certainly similar in the leys of the long-term experiment, in which the highest rate of $\mathrm{P}$ fertilisation was even higher than in the short-term experiment in ley.

Since no more than $2 \mathrm{~cm}$ of the uppermost soil is exposed to leaching by surface runoff (Sharpley 1985), the transfer of surface-applied $\mathrm{P}$ to streams and lakes is not properly predicted by any soil tests based on the samples obtained from the whole plough layer in the usual manner. For environmental purposes the enriched surface should be assessed separately by means of samples obtained form a thin layer of the surface soil, and fairly frequent tests are required for assessing the rapid changes in potentially transportable P. Much less frequent sampling is sufficient for measuring the slow and fairly well predictable changes in the STP values of soils which are regularly homogenised by a deep primary tillage.

\section{Summary and conclusions}

The changes of total $\mathrm{P}$ and soil test $\mathrm{P}$ values caused by different rates of repeated $P$ fertilisation were monitored for 22 diverse Finnish soils enriched with large amounts of accumulated fertiliser P. Several chemical soil testing methods were compared at 19 sites and the Finnish ammonium acetate method was employed at three additional sites. The differences in total $\mathrm{P}$ between the fertilisation rates of 15 and $45 \mathrm{~kg} P$ $\mathrm{ha}^{-1}$ observed by chemical analysis in the topsoil layer accounted for $65 \%$ of the calculated balance surpluses during the experimental peri- od of 9 to 15 years. Because of the $P$ gained by soil exchange between adjacent plots and probably saved with more efficient utilisation of the deeper soil layers in the area not fertilised with $\mathrm{P}$, the recovery percentage of applied $\mathrm{P}$ was lower between the smallest rate and the control.

Modified Olsen $\mathrm{P}\left(\mathrm{P}_{\mathrm{Olm}}\right)$ accounted for $9.7 \%$ $\left(0.058 \mathrm{mg} \mathrm{kg}^{-1}\right) /\left(\mathrm{kg} \mathrm{ha}^{-1}\right)$ of the balance differences between the $\mathrm{P}$ application rates of 0 and $45 \mathrm{~kg} \mathrm{ha}^{-1}$, and the recoveries were similar in all types of soil and even at individual sites almost independent of their $\mathrm{P}$ status. With acetate and water extraction methods $\left(\mathrm{P}_{\mathrm{Ac}}\right.$ and $\left.\mathrm{P}_{\mathrm{w}}\right)$ the corresponding mean recoveries were 3.5 and $4.7 \%$ $\left(0.0159\right.$ and $\left.0.0214 \mathrm{mg} \mathrm{dm}^{-3}\right) /\left(\mathrm{kg} \mathrm{ha}^{-1}\right.$ in $\mathrm{P}$ balance), but they increased steeply with increasing initial STP values for both methods. $\mathrm{P}_{\mathrm{Olm}}$ indicated mainly the capacity factor of soil $\mathrm{P}$ status, while the more sensitive $\mathrm{P}_{\mathrm{Ac}}$ and $\mathrm{P}_{\mathrm{w}}$ values appeared to predict primarily the intensity factor of $\mathrm{P}$ status in acidic mineral soils. The $\mathrm{P}$ surpluses up to $500 \mathrm{~kg} \mathrm{ha}^{-1}$ were insufficient to rise the STP values any more than required for optimum yields in the poorest soils which efficiently fixed applied phosphate.

At zero $\mathrm{P}$ balance, when the P offtake by harvested crops was replaced with fertilisation, most of the initially low and medium $\mathrm{P}_{\mathrm{Ac}}$ values remained unchanged during the experimental period. Considerable losses of extractable $\mathrm{P}$ were found in initially acidic and acidified fine-textured soils, in one clay-amended organic soil formerly poor in extractable $\mathrm{P}$, and in all soils which were initially rich in extractable P. Direct observations and indirect estimations from the changes in the concentration of total $\mathrm{P}$ suggested that some unplanned mixing of the poorer subsurface soil with the topsoil by ploughing decreased the $\mathrm{P}$ values for the final samples for all methods.

The decrease in the trend values of the final $\mathrm{P}_{\mathrm{Ac}}$ at zero balance as a function of the initial values was $10 \%$ at $5 \mathrm{mg} \mathrm{P} \mathrm{dm}^{-3}$ and $19 \%$ at 25 $\mathrm{mg} \mathrm{dm}^{-3}$. These decreases corresponded to 70 and $190 \mathrm{~kg} \mathrm{ha}^{-1}$ of applied P during the experimental period and annual balance surpluses of $6-15 \mathrm{~kg}$ $\mathrm{ha}^{-1}$ (mean $10 \mathrm{~kg} \mathrm{ha}^{-1}$ ). These amounts of ferti- 


\section{Saarela, I. et al. Phosphorus status of Finnish soils and long-term P fertilisation}

liser $\mathrm{P}$ were required in addition to the offtake in harvested crops to completely prevent the decrease in STP and maintain the P status of soil as estimated by the acetate method.

The results suggest that the slow and regular changes of the $\mathrm{P}$ status in Finnish mineral soils can be assessed accurately enough by relatively infrequent soil tests when the topsoil is frequently homogenised with deep primary tillage. Extending the agro-environmental soil testing program to the subsoil depth appeared highly relevant to the deep peat profiles which are poor in the minerals capable to retain soluble phosphate. The effect of broadcast application of $\mathrm{P}$ on the STP values of ley soil was much greater in the $2.5 \mathrm{~cm}$ thick surface layer than in the whole 20$25 \mathrm{~cm}$ deep topsoil. Testing a thin layer of the enriched soil surface for extractable $\mathrm{P}$ by means of separate environmental samples seems to be necessary for accurate estimation of the risk of increased $\mathrm{P}$ leaching after repeated application of $\mathrm{P}$ on the soil surface, as is usually done in leys.

Acknowledgements. This research project was initiated by the late Professor Paavo Elonen. The field experiments were conducted by the Soils and Environment unit in Jokioinen and at MTT's research stations by local staff under local direction. The soil and plant samples were analysed in the laboratories of the Institute of Environmental Research. Most of the soil analyses were carried out under the direction of Professor Jouko Sippola. The contributions of all scientists and technical experts who collaborated within this large project are greatly appreciated.

\section{References}

Aura, E. 1967. Effect of the placement of fertilizer on the development of spring wheat. Journal of the Scientific Agricultural Society of Finland 39: 148-155.

Barkoff, E. 1959. Über die Fraktionierung der Bodenphosphate unter Verwendung eines automatischen Apparates mit lonenaustauscher. Acta Agralia Fennica 94: 165-199.

Carlgren, K. \& Mattsson, L. 2001. Swedish soil fertility experiments. Acta Agriculturae Scandinavica, Section B, Soil and Plant Science 51: 49-78.
Erviö, R. 1970. The important of soil bulk density in soil testing. Annales Agriculturae Fenniae 9: 278-286.

Finck, A. 1992. Dünger und Düngung. 2. Aufl. VHC Verlagsgesellschaft, Weinheim. 488 p.

Håkansson, I., Stenberg, M. \& Rydberg, T. 1998. Longterm experiments with different depths of mouldboard ploughing in Sweden. Soil \& Tillage Research 46: 209-223.

Hänninen, P. \& Kaila, A. 1960. Field trials on the store dressing with rock phosphate. The Journal of the Scientific Agricultural Society of Finland 32: 107-117.

Haygarth, P.M., Hepworth, L. \& Jarvis, S.C. 1998. Forms of phosphorus transfer in hydrological pathways form soil under grazed grassland. European Journal of Soil Science 49: 654-672.

Hooda, P.S., Rendell, A.R., Edwards, A.C., Withers, P.J.A., Aitken, M.N. \& Truesdale, V.W. 2000. Relating soil phosphorus indices to potential phosphorus release in water. Journal of Environmental Quality 29: 11661171.

Huhta, H. \& Jaakkola, A. 1993. Viljelykasvin ja lannoituksen vaikutus ravinteiden huuhtoutumiseen turvemaasta Tohmajärven huuhtoutumiskentällä v. 198387. (Effects of crop and fertilisation on the leaching of nutrients from a peat soil in the leaching field at Tohmajärvi in 1983-87.) Maatalouden tutkimuskeskus, Tiedote 20/93: 66 p. +7 app.

Jaakkola, A., Hakkola, H., Köylijärvi, J. \& Simojoki, P. 1977. Effect of liming on phosphorus fertilizer requirement in cereals and ley. Annales Agriculturae Fenniae 16: 207-219.

Jaakkola, A., Hartikainen, H. \& Lemola, R. 1997. Effect of fertilization on soil phosphorus in a long-term field experiment in Southern Finland. Agricultural and Food Science in Finland 6: 313-322.

Jokela, W.E., Magdoff, F.R. \& Durieux, R.P. 1998. Improved phosphorus recommendations using modified Morgan phosphorus and aluminum soil tests. Communications in Soil Science and Plant Analysis 29: 1739-1749.

Kähäri, J. \& Nissinen, H. 1978. The mineral element contents of timothy (Phleum pratense L.) in Finland. I. Calcium, magnesium, phosphorus, potassium, chromium, cobalt, copper, iron, manganese, sodium and zinc. Acta Agriculturae Scandinavica Supplement 20: 26-39.

Kaila, A. 1959. Retention of phosphate by peat samples. The Journal of the Scientific Agricultural Society of Finland 31: 215-224.

Kaila, A. 1961. Fertilizer phosphorus in some Finnish soils. The Journal of the Scientific Agricultural Society of Finland 33: 131-139.

Kaila, A. \& Missilä, H. 1956. Accumulation of fertilizer phosphorus in peat soils. The Journal of the Scientific Agricultural Society of Finland 28: 168-178.

Kuntze, H. \& Scheffer, B. 1979. Die Phosphatmobilität im Hochmoorboden in Abhängigkeit von der Düngung. Zeitschrift für Pflanzenernährung und Bodenkunde 142: 155-168.

Lakanen, E. \& Vuorinen, J. 1963. The effect of liming on the solubility of nutrients in various Finnish soils. Annales Agriculturae Fenniae 2: 91-102. 
Vol. 13 (2004): 276-294.

Luostarinen, H. 1967. Vaaramoreenin lannoitus- ja kalkituskokeen tuloksia. Summary: Results from a fertilizing and liming test on hill moraine. Journal of the Scientific Agricultural Society of Finland 39: 193-204.

Maguire, R.O., Foy, R.H., Bailey, J.S. \& Sims, J.T. 2001. Estimation of the phosphorus sorption capacity of acidic soils in Ireland. European Journal of Soil Science 52: 479-487.

Mäkelä-Kurtto, R. \& Sippola, J. 2002.Monitoring of Finnish arable land: changes in soil quality between 1987 and 1998. Agricultural and Food Science in Finland 11: 273-284.

Peltovuori, T. 2002. Phosphorus extractability in surface soil samples as affected by mixing with subsoil. Agricultural and Food Science in Finland 11: 371-379.

Peltovuori, T., Uusitalo, R. \& Kauppila, T. 2002. Phosphorus reserves and apparent phosphorus saturation in four weakly developed cultivated pedons. Geoderma 10: 35-47.

Puustinen, M., Merilä, E., Palko, J. \& Seuna, P. 1994. Kuivatustila, viljelykäytäntö ja vesistökuormitukseen vaikuttavat ominaisuudet Suomen pelloilla. Abstract: Drainage level, cultivation practices and factors affecting load on waterways in Finnish farmland. Publications of National Board of Waters and the Environment - Series A 198. $323 \mathrm{p}$.

Saarela, I. 1992a. Agronomic efficiency and environmental effects of large doses of phosphorus with establishment vs. annual topdressing in leys. Proceedings of the 14th General Meeting of the European Grassland Federation. Lahti, 8-11 June 1992. p. 528-530.

Saarela, I. 1992b. A simple diffusion test for soil phosphorus availability. Plant and Soil 147: 115-126.

Saarela, I. 1998. Problem soils in Finland require more phosphorus. Kungl. Skogs- och Lantbruksakademiens Tidskrift 135: 43-44.

Saarela, I. 2002. Phosphorus in Finnish soils in the 1900s with particular reference to the acid ammonium acetate soil test. Agricultural and Food Science in Finland 11: 257-271.

Saarela, I., Järvi, A., Hakkola, H. \& Rinne, K. 1995. Fosforilannoituksen porraskokeet 1977-1994. Summary: Phosphorus fertilizer rate trials, 1977-1994. Maatalouden tutkimuskeskus, Tiedote 16/95. 94 p. + 14 app.

Saarela, I., Järvi, A., Hakkola, H. \& Rinne, K. 2003. Phosphorus status of diverse soils in Finland as influences by long-term $P$ fertilisation. I. Native and previously applied P at 24 experimental sites. Agricultural and Food Science in Finland 12: 117-132.

Saarela, I. Kakkonen. K. \& Salo, Y. 2000. Savimaan fosforin satavuuden parantaminen runsaalla kalkituksella sekä ruokamullan ja fosforin syvämultauksella. Summary: Improving the availability of phosphorus in clay soils by heavy liming and by deep incorporation of topsoil and phosphorus. Maatalouden tutkimuskeskuksen julkaisuja. Sarja A. 51 p. +8 app.
Saarela, I. \& Saarela, K. 2000. Mapping spatial variation of diffusible soil $\mathrm{P}$ by in situ colouring in Fe-oxide paper. Communications in Soil Science and Plant Analysis 31: 2019-2025.

Saarela, I. \& Sippola, J. 1990. Inorganic leaf phosphorus and soil tests as indicators of phosphorus nutrition in cereals. Communications in Soil Science and Plant Analysis 21: 1927-1943.

Salonen, M. \& Tainio, A. 1957. Fosforilannoitusta koskevia tutkimuksia. Summary: Results of field experiments with different amounts of phosphate fertilizers. Publications of the Finnish State Agricultural Research Board 164. 104 p.

Sharpley, A. N. 1985. Depth of surface soil-runoff interaction as affected by rainfall, soil slope and management. Soil Science Society of America Journal 49: 1010-1015.

Sibbesen, E., Skjoth, F. \& Rubak, G.H. 2000. Tillage caused dispersion of phosphorus and soil in four 16year old field experiments. Soil \& Tillage Research 54: 91-100.

Sillanpää, M. 1982. Micronutrients and the nutrient status of soils: a global study. FAO Soils Bulletin 48. 444 p.

Sillanpää, M. \& Rinne, S.-L. 1975. The effect of heavy nitrogen fertilization on the uptake of nutrients and on some properties of soils cropped with grasses. Annales Agriculturae Fenniae 14:210-226.

Sippola, J. \& Saarela, I. 1986. Some extraction methods as indicators of need for phosphorus fertilization. Annales Agriculturae Fenniae 25: 265-271.

Turtola, E. 1999. Phosphorus in surface runoff and drainage water affected by cultivation practices. Agricultural Research Centre of Finland, Academic Dissertation. 47 p. + app.

Turtola, E. \& Yli-Halla, M. 1999. Fate of phosphate applied in slurry and mineral fertilizer: accumulation in soil and release into surface runoff water. Nutrient Cycling in Agroecosystems 55: 165-174.

Virkajärvi, P. \& Huhta, H. 1993. Nurmen viljely polttoturvesoiden jättöalueilla. Timoteinurmen fosforilannoitus Tohmajärven Valkeasuolla. Summary: Grass Production on cut-away peatlands. Phosphorus fertilization for Timothy (Phleum pratense L.) leys at Valkeasuo, Tohmajärvi. Maatalouden tutkimuskeskus, Tiedote $7 / 93.27$ p. +2 app.

Vuorinen, J. \& Mäkitie, O. 1955. The method of soil testing in use in Finland. Agrogeological Publications 63. $44 \mathrm{p}$.

Yli-Halla, M. 1989. Effect of different rates of $P$ fertilization on the yield and $\mathrm{P}$ status of the soil in two longterm field experiments. Journal of Agricultural Science in Finland 61: 361-370.

Yli-Halla, M., Hartikainen, H. \& Väätäinen, P. 2002. Depletion of soil phosphorus as assessed by several indices of phosphorus supplying power. European Journal of Soil Science 53: 431-438. 


\title{
SELOSTUS
}

\section{Pitkäaikaisen fosforilannoituksen vaikutus Suomen peltojen fosforitilaan. 2. Kemiallisten testien muutokset suhteessa fosforitaseeseen sekä aikaisemmin ja koevuosina lisätyn fosforin multaussyvyyteen}

\author{
Into Saarela, Aulis Järvi, Heikki Hakkola ja Kalle Rinne \\ MTT (Maa- ja elintarviketalouden tutkimuskeskus)
}

Fosforilannoituksella tehostetaan kasvintuotantoa ja turvataan välttämättömän kasvutekijän jatkuva saanti kestävän maatalouden vaatimusten mukaisesti. Hyvien satojen edellyttämän maan fosforitilan saavuttamiseen ja ylläpitoon tarvittavaa lannoitusta tutkittiin pitkäaikaisilla kenttäkokeilla 22 koepaikalla ominaisuuksiltaan vaihtelevilla mailla, joihin oli edellisinä vuosikymmeninä kertynyt runsaasti fosforia. Viiden vuosittain annetun fosforimäärän $(0,15,30,45$ ja $60 \mathrm{~kg} \mathrm{ha}^{-1}$ ) vaikutuksia maan fosforitilaan tutkittiin useilla kemiallisilla menetelmillä 9-15 koevuoden jälkeen, ja analyysituloksia verrattiin pellon fosforitaseeseen. Nurmelle levitetyn fosforin kerrostumista tutkittiin neljällä koepaikalla.

Fosforilannoituksen koko kyntökerroksessa aiheuttamat maan fosforipitoisuuden keskimääräiset erot prosentteina fosforitaseesta olivat asetaattitestillä 3,5\% (0,0159 $\mathrm{mg} \mathrm{P} \mathrm{dm}^{-3}$ maata)/(P-taseen ero $1 \mathrm{~kg}$ $\left.\mathrm{ha}^{-1}\right)$, vesiuutolla $4,7 \%\left(0,0214 \mathrm{mg} \mathrm{P} \mathrm{dm}^{-3}\right) /\left(\mathrm{kg} \mathrm{P} \mathrm{ha}^{-1}\right)$ ja Olsenin menetelmällä $9,7 \%\left(0,058 \mathrm{mg} \mathrm{P} \mathrm{kg}^{-1}\right) /(\mathrm{kg}$ $\left.\mathrm{P} \mathrm{ha}^{-1}\right)$. Mailla, jotka pidättivät liukoista fosforia tehokkaimmin, enimmillään yli $500 \mathrm{~kg} \mathrm{ha}^{-1}$ sadoissa poistuneita suuremmat fosforimäärät eivät riittäneet nostamaan asetaatti- ja vesiuutolla määritettyjä fosforipitoisuuksia enempää kuin hyvään kasvuun tar- vittiin. Alussa korkeat asetaattiuuttoisen fosforin pitoisuudet pienenivät hitaasti fosforilannoituksen ollessa yhtä suuri kuin fosforin poistuma sadoissa, mutta pienet alkupitoisuudet eivät muuttuneet ilman erityistä syytä kuten maan happamoitumista ja niukkafosforisen jankon sekoittumista kyntökerrokseen. Asetaattimenetelmän mukaan lannoitefosforia tarvittiin maan fosforitilan ylläpitoon keskimäärin noin 10 $\mathrm{kg} \mathrm{ha}^{-1}$ enemmän kuin sadoissa poistui.

Tulosten mukaan syvällä perusmuokkauksella homogenisoitujen kivennäismaiden fosforitilan hitaat ja säännölliset muutokset voidaan määrittää riittävän tarkasti ja luotettavasti suhteellisen harvoin tehtävillä viljavuustutkimuksilla. Maatalouden ympäristönsuojelua varten turvemaiden liukoisen fosforin pitoisuus tulisi määrittää myös muokkauskerrosta syvempää. Pintalannoitettujen nurmien ohut pintakerros rikastui paljon nopeammin kuin koko kyntökerros. Jos fosforia levitetään maan pinnalle toistuvasti ilman välillä tehtävää kunnollista multausta, huuhtoutumisriskin luotettava arviointi edellyttää pintaa pitkin valuvan veden huuhtoman maan tutkimista erikseen ohuesta pintakerroksesta otetuttujen maanäytteiden avulla. 